\title{
Influence of Texture on the Mechanical Properties of a Mg-6Al-1Zn-0.9Sn Alloy Processed by ECAP
}

\author{
Hong Xu, Zhi-Peng Guo, Ping-Yu Zhang, You Zhou and Pin-Kui Ma*
}

Citation: Xu, H.; Guo, Z.-P.; Zhang, P.-Y.; Zhou, Y.; Ma, P.-K. Influence of Texture on the Mechanical Properties of a Mg-6Al-1Zn-0.9Sn Alloy Processed by ECAP. Materials 2021, 14, 2664. https://doi.org/10.3390/ ma14102664

Academic Editors: Jan Awrejcewicz and Virgil-Florin Duma

Received: 12 April 2021

Accepted: 11 May 2021

Published: 19 May 2021

Publisher's Note: MDPI stays neutral with regard to jurisdictional claims in published maps and institutional affiliations.

Copyright: (c) 2021 by the authors. Licensee MDPI, Basel, Switzerland. This article is an open access article distributed under the terms and conditions of the Creative Commons Attribution (CC BY) license (https:// creativecommons.org/licenses/by/ $4.0 /)$.
Key Laboratory of Automobile Materials of Ministry of Education, School of Materials Science and Engineering, Nanling Campus, Jilin University, No. 5988 Renmin Street, Changchun 130025, China; xh@jlu.edu.cn (H.X.); guozp18@mails.jlu.edu.cn (Z.-P.G.); zpy17@mails.jlu.edu.cn (P.-Y.Z.); zhouyou17@mails.jlu.edu.cn (Y.Z.)

* Correspondence: mapk@jlu.edu.cn; Tel./Fax: +86-431-8509-4375

\begin{abstract}
The microstructure and mechanical properties of a Mg-6Al-1Zn-0.9Sn alloy processed by equal channel angular pressing (ECAP) at temperatures of $250^{\circ} \mathrm{C}$ and $300^{\circ} \mathrm{C}$ were investigated. It was found that the refinement of the microstructure was very dependent on the processing temperature. The main reason for the difference in grain refinement was the precipitation of secondary-phase particles. Texture information obtained by electron back-scatter diffraction (EBSD) showed the gradual formation of a $45^{\circ}$ texture during the ECAP process, while the maximum intensity was different for processing temperatures at $250^{\circ} \mathrm{C}$ and $300^{\circ} \mathrm{C}$. By calculating the contribution from different strengthening mechanisms, it was found that a $45^{\circ}$ texture had a huge influence on grain boundary strengthening and thus the yield strength.
\end{abstract}

Keywords: ECAP; microstructure evolution; weaken texture; mechanical properties; magnesium alloys

\section{Introduction}

The advantages of their high specific strength give magnesium $(\mathrm{Mg})$ alloys wide prospects for lightweight applications in the aerospace, automotive, and electronic fields [1,2]. However, the low formability and strong plastic anisotropy of $\mathrm{Mg}$ alloys limit the development of their wider industrial applications [3,4]. Now, some new types of $\mathrm{Mg}$ alloys have been developed based on the common $\mathrm{Mg}-\mathrm{Al}-\mathrm{Zn}$ system, which is by adding extra rare earth elements [5,6]. The rare earth elements (such as $\mathrm{Nd}$ and $\mathrm{Ce}[5,6]$ ) can effectively ameliorate the formability of $\mathrm{Mg}$ alloys at room temperature (RT). Compared with expensive rare earth elements, adding the inexpensive Sn element to $\mathrm{Mg}$ alloys can improve not only their creep resistance, but also the mechanical strength and toughness at RT $[7,8]$.

As is well known, microstructure refinement is also one of effective ways of improving the mechanical properties of alloys [9]. Thus, many research works have been devoted to achieving microstructure refinement by thermo-mechanical processes, such as extrusion and rolling $[10,11]$. Nevertheless, the microstructure refinement obtained by this processing is not enough to greatly improve the mechanical properties of magnesium alloys. Therefore, obtaining better microstructure refinement by proper processing is still the research focus of Mg alloys [12-14].

Severe plastic deformation (SPD) techniques have been proven to be effective in producing an ultra-fine microstructure, such as high-pressure torsion (HPT), asymmetric rolling (ASR), and ECAP [15-20]. In recent years, some research has been carried out on processing $\mathrm{Mg}$ alloys by ECAP $[15,17,19]$. Overall, the researches on Mg alloy ECAP include two aspects: microstructure refinement and texture modification [21-24]. Although ECAP can refine grains, the high strength and toughness may not be necessarily achieved. The yield strength of $\mathrm{Mg}$ alloys may be reduced after ECAP, especially those with strong basal textures [17,25-29]. How to ensure the reasonable match between microstructure refinement and texture modification during ECAP is the critical point to improve strength 
and toughness. Therefore, exploring the influence of microstructure refinement and texture modification on the mechanical properties of ECAP-processed $\mathrm{Mg}$ alloys is essential.

Although many research works on ECAP-processed Mg alloys have been reported, few studies have systematically analyzed the relationship among their microstructure, texture, and mechanical properties. Thus, the present work studied how the deformation temperatures $\left(250^{\circ} \mathrm{C}\right.$ and $\left.300^{\circ} \mathrm{C}\right)$ affect the grain refinement, precipitation, texture evolution, and mechanical properties of an ECAP-processed Mg-6Al-1Zn-0.9Sn alloy.

\section{Experimental Procedure}

The $10 \mathrm{~mm}$ thickness extruded Mg-6Al-1Zn-0.9Sn (wt. \%, ATZ611) plate was used in this work. Before EACP, the extruded ATZ611 plate was solutionized at $420^{\circ} \mathrm{C}$ for $20 \mathrm{~h}$, then quenched. The as-solutionized ATZ611 plate was cut into $10 \mathrm{~mm} \times 10 \mathrm{~mm} \times 80 \mathrm{~mm}$ barshaped ECAP samples along the extrusion direction. The ECAP samples were deformed through a $90^{\circ} \mathrm{ECAP}$ die using route $\mathrm{Bc}$. Route $\mathrm{Bc}$ is when the next pass is rotated $90^{\circ}$ in the same direction relative to the previous pass. When ECAP processed by this die, the single-pass strain $\varepsilon=1.1$. Considering that when the deformation temperature is lower than $250{ }^{\circ} \mathrm{C}$, the samples will be broken in the ECAP process and the deformation temperature is too high to achieve the purpose of grain refinement, the deformation temperature of ECAP in this paper was selected as follows: $250^{\circ} \mathrm{C}$ and $350^{\circ} \mathrm{C}$. Before ECAP, the temperature of the ECAP die was heated to the desired temperatures $\left(250^{\circ} \mathrm{C}\right.$ and $\left.350{ }^{\circ} \mathrm{C}\right)$ and maintained for $30 \mathrm{~min}$. Then, the ECAP sample was placed in the ECAP die for $15 \mathrm{~min}$ to reach the deformation temperatures $\left(250^{\circ} \mathrm{C}\right.$ and $\left.350^{\circ} \mathrm{C}\right)$ as well. A self-made temperature control system was used to control the temperature. For convenience, the deformed samples after $X$ passes are referred to as the XP samples. The schematic of the ECAP process is shown in Figure 1a, where the ECAP sample was extruded from the vertical channel into the horizontal channel under the action of the punch rod.
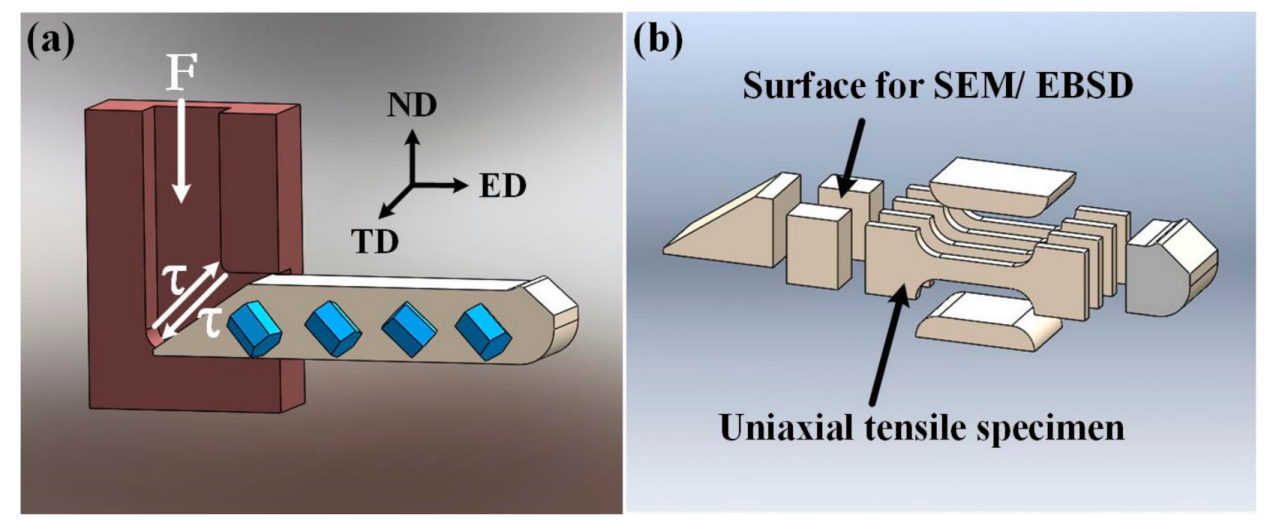

Figure 1. (a) Schematic of the ECAP process. (b) Samples for microstructure characterization and tensile tests.

Microstructure characterization was conducted by scanning electron microscopy (SEM: ZEISS EVO18, Oberkochen, Germany) and electron backscatter diffraction (EBSD: Oxford NordlysNano, Oxford, UK). Phase analysis was performed by an X-ray diffractometer (XRD: D/Max 2500PC Rigaku, Tokyo, Japan), using a Cu target K $\alpha$-ray $(\lambda=1.5406 \AA$ ). RT tensile tests were implemented using a SHIMADZU AGS-100kN machine (Tokyo, Japan), with a stain rate of $1 \times 10^{-3} \mathrm{~s}^{-1}$. The $10 \mathrm{~mm} \times 4 \mathrm{~mm} \times 1.5 \mathrm{~mm}$ tensile samples were cut along the ED (Figure $1 b$ ).

\section{Results and Discussion}

\subsection{Microstructure Evolution During ECAP}

IPF maps and a \{0001\} pole figure of the as-solutionized ATZ611 alloy are shown in Figure 2. The as-solutionized ATZ611 alloy exhibited a uniform equiaxed grain structure delineated by well-defined boundaries, with $d_{\text {ave }}$ of $\sim 26.2 \mu \mathrm{m}$. The $\{0001\}$ pole figure 
indicated a strong basal texture (Figure $2 b$ ) with a maximum intensity of $20.9 \mathrm{mr}$, which was analogous to the typical basal textures of extrusion plates reported in previous studies [30,31].
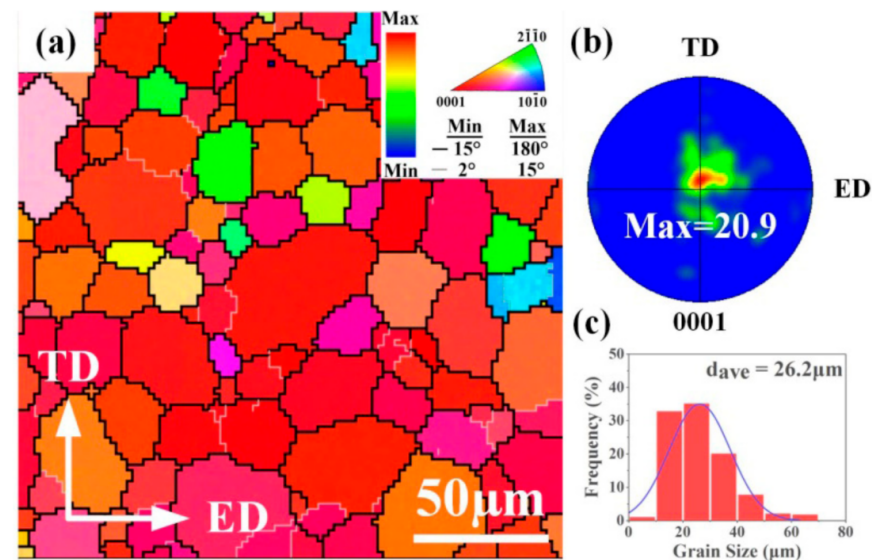

Figure 2. (a) IPF map, (b) $\{0001\}$ pole figure, and (c) grain size distribution of the as-solutionized sample.

Figure 3 shows IPF maps of $250{ }^{\circ} \mathrm{C}$-ECAP samples and $300{ }^{\circ} \mathrm{C}$-ECAP samples. Their corresponding $\mathrm{d}_{\text {ave }}$ are shown in Table 1 . After one pass (Figure 3a), a heterogeneous grain structure was formed in the $250{ }^{\circ} \mathrm{C}-1 \mathrm{P}$ sample, with the $\mathrm{d}_{\text {ave }}$ decreased to $6.2 \mu \mathrm{m}$ compared to the as-solutionized ATZ611 alloy. Nearly 70\% of the grains had sizes less than $5 \mu \mathrm{m}$. The formation of heterogeneous grain structures at 1PECAP of the ATZ611 alloys agreed with the results of Figueiredo et al. [17]. If the $d_{\text {ave }}$ before ECAP were higher than a critical size, the refinement would start inhomogeneously with fine grains forming at the original grain boundaries for a few ECAP passes. For the ECAP-processed AZ31 alloy, the critical size for the formation of a bimodal size distribution was between 3 and $9 \mu \mathrm{m}$. Therefore, the formation of bimodal microstructures after one pass of ECAP in Figure 3 a was because of the initial large grain size $(\sim 26 \mu \mathrm{m})$. As shown in Figure $3 \mathrm{~b}$, the size distribution of $250{ }^{\circ} \mathrm{C}-2 \mathrm{P}$ samples became more homogeneous, and $\mathrm{d}_{\text {ave }}$ was measured to be $\sim 3.6 \mu \mathrm{m}$ (Figure $3 \mathrm{e}$ ). After four passes of ECAP, grains became further refined, with $\mathrm{d}_{\text {ave }}$ being $\sim 1.9 \mu \mathrm{m}$.

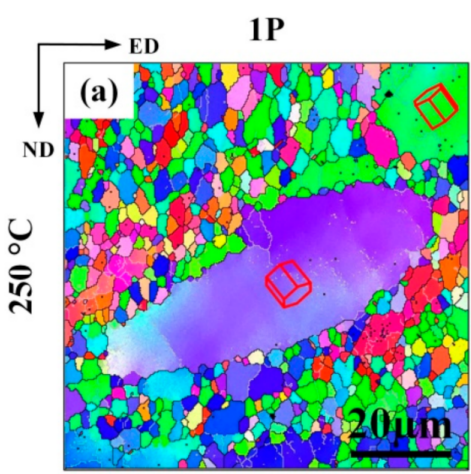

2P
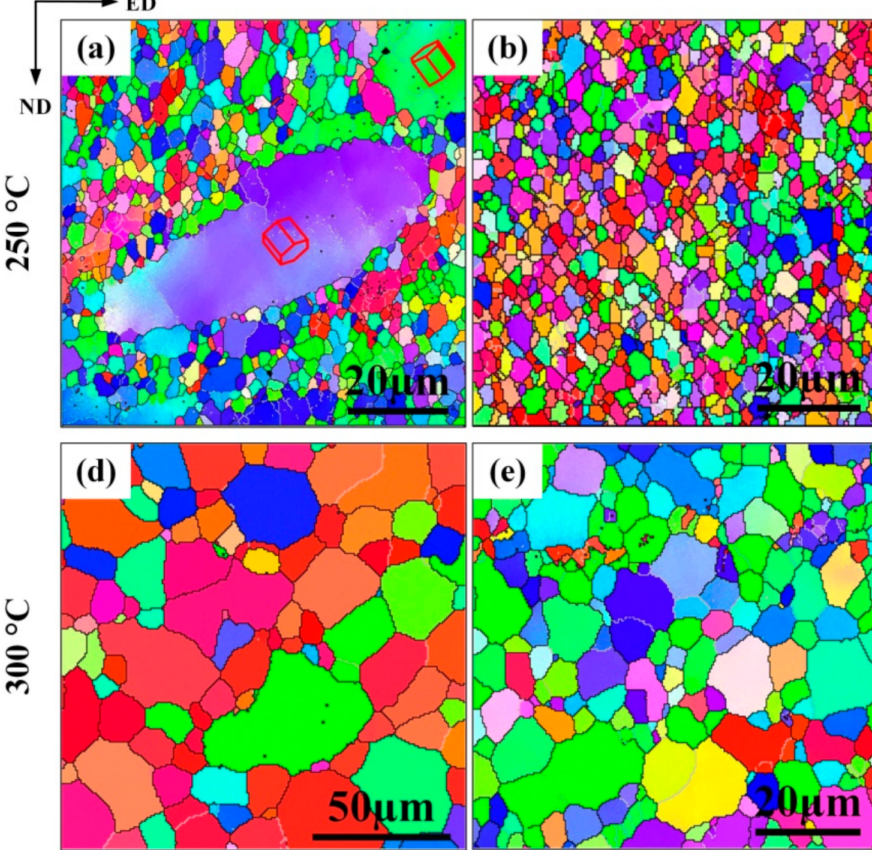

(e)

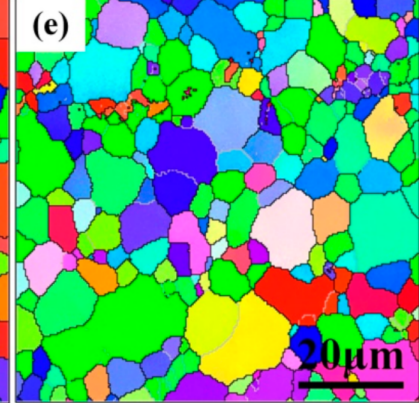

4P
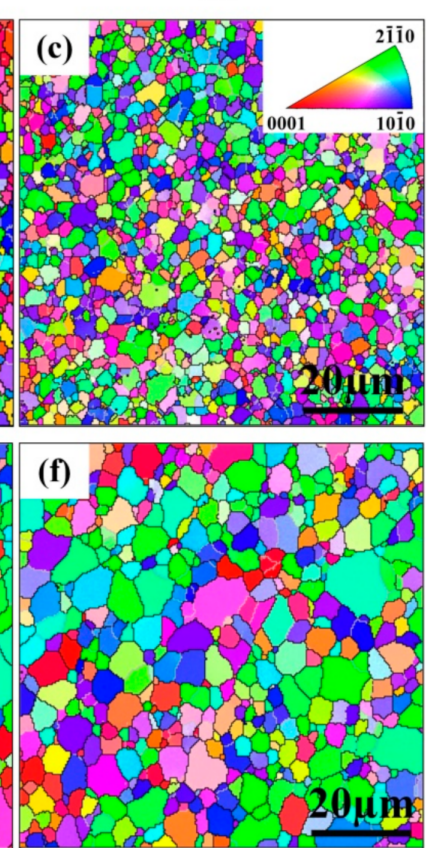

Figure 3. IPF maps of $(\mathbf{a}, \mathbf{b}, \mathbf{c}) 250{ }^{\circ} \mathrm{C}$-ECAP samples and $(\mathbf{d}, \mathbf{e}, \mathbf{f}) 300^{\circ} \mathrm{C}-\mathrm{ECAP}$ samples. (a,d) 1 pass, (b,e) 2 passes, and (c,f) 4 passes. 
Table 1. Microstructure characteristics of the ECAP samples.

\begin{tabular}{ccccc}
\hline Sample & $\mathbf{d}_{\text {ave }}(\boldsymbol{\mu \mathbf { m }})$ & $\mathbf{d}_{\mathbf{p}}(\mathbf{n m})$ & $\mathbf{f}_{\mathbf{p}} \mathbf{( \% )}$ & $\left.\boldsymbol{\rho ~ ( 1 0 ~}^{\mathbf{1 2}} \mathbf{m}^{-\mathbf{2}}\right)$ \\
\hline As-solutionized & 26.2 & - & - & - \\
$250^{\circ} \mathrm{C}-1 \mathrm{P}$ & 6.2 & 400 & 17 & 6.05 \\
$250^{\circ} \mathrm{C}-2 \mathrm{P}$ & 3.6 & 500 & 20 & 2.96 \\
$250^{\circ} \mathrm{C}-4 \mathrm{P}$ & 1.9 & 580 & 12 & 6.13 \\
$300^{\circ} \mathrm{C}-1 \mathrm{P}$ & 16.5 & 430 & 5 & 1.14 \\
$300^{\circ} \mathrm{C}-2 \mathrm{P}$ & 8.6 & 430 & 3 & 2.86 \\
$300^{\circ} \mathrm{C}-4 \mathrm{P}$ & 5.5 & 350 & 2 & 2.23 \\
\hline
\end{tabular}

Compared with the $250^{\circ} \mathrm{C}$ sample, it was clear that there were no elongated coarse grains in the $300^{\circ} \mathrm{C}-1 \mathrm{P}$ sample (Figure $3 \mathrm{~d}$ ). The $\mathrm{d}_{\text {ave }}$ is $\sim 16.5 \mu \mathrm{m}$, which was larger than that of the $250{ }^{\circ} \mathrm{C}-1 \mathrm{P}$ sample. With further increasing the ECAP passes, the grain structure became more uniform. However, it was quite clear that higher deformation temperature led to slow grain refinement during ECAP, resulting in larger grains.

XRD photos of the as-solutionized sample and ECAPed samples deformed at $250{ }^{\circ} \mathrm{C}$ and $300^{\circ} \mathrm{C}$ are shown in Figure 4. It indicates that after the solution's heat treatment, nearly all the secondary phase particles in the ATZ611 alloy dissolved into the $\alpha$-Mg matrix, while a few $\mathrm{Al}_{8} \mathrm{Mn}_{5}$ phases remained. After one pass of ECAP at $250{ }^{\circ} \mathrm{C}$, the diffraction peaks of the $\mathrm{Mg}_{17} \mathrm{Al}_{12}$ phase appeared, with the highest peak intensity at $2 \theta=36.74^{\circ}$. During ECAP, dynamic precipitation of the $\mathrm{Mg}_{17} \mathrm{Al}_{12}$ phase was due to the increasing dislocations, and vacancies could accelerate the diffusion of alloying elements [32,33]. For the $250{ }^{\circ} \mathrm{C}-2 \mathrm{P}$ samples, the intensity of the $\mathrm{Mg}_{17} \mathrm{Al}_{12}$ diffraction peaks increased, and the diffraction peaks of the $\mathrm{Mg}_{2} \mathrm{Sn}$ phase appeared.

In contrast, for the $300{ }^{\circ} \mathrm{C}-1 \mathrm{P}$ sample, the peak intensities of the $\mathrm{Mg}_{17} \mathrm{Al}_{12}$ phase were lower, which may be due to the faster recover of dislocations and vacancies. Moreover, obvious diffraction peaks of the $\mathrm{Mg}_{2} \mathrm{Sn}$ phase could not be seen for the $300{ }^{\circ} \mathrm{C}-2 \mathrm{P}$ sample. It was proven that the precipitation of the $\mathrm{Mg}_{2} \mathrm{Sn}$ phase could nucleate at the edge-tip of the $\mathrm{Mg}_{17} \mathrm{Al}_{12}$ phase [34]. If the precipitated amount of the $\mathrm{Mg}_{17} \mathrm{Al}_{12}$ phase were small, then the precipitation of $\mathrm{Mg}_{2} \mathrm{Sn}$ would be small as well.

Figure 5 shows SEM images of samples deformed at $250{ }^{\circ} \mathrm{C}$, with the $d_{p}$ and $f_{p}$ of the secondary-phase partials summarized in Table 1. Combined with the XRD in Figure $4, \mathrm{Al}_{8} \mathrm{Mn}_{5}$ particles with sizes of $5-10 \mu \mathrm{m}$ could be observed in the $250{ }^{\circ} \mathrm{C}-1 \mathrm{P}$ sample (Figure 5a). Many $\sim 400 \mathrm{~nm}$ spot-shaped $\mathrm{Mg}_{17} \mathrm{Al}_{12}$ phases precipitated in the area of fine grains, while almost no phase particles were inside the elongated deformed grains. Upon increasing the ECAP passes to two, the particle distribution became more uniform, and many $\mathrm{Mg}_{17} \mathrm{Al}_{12}$ particles were located at the grain boundaries, while large $\mathrm{Al}_{8} \mathrm{Mn}_{5}$ particles were broken (Figure $5 \mathrm{~b}$ ). After four passes, no large $\mathrm{Al}_{8} \mathrm{Mn}_{5}$ particles remained (Figure 5c). During ECAP deformation, fine fragmented $\mathrm{Al}_{8} \mathrm{Mn}_{5}$ and sub-micron $\mathrm{Mg}_{17} \mathrm{Al}_{12}$ particles could pin the boundaries and hinder the growth of recrystallized grains effectively $[35,36]$. 
(a)

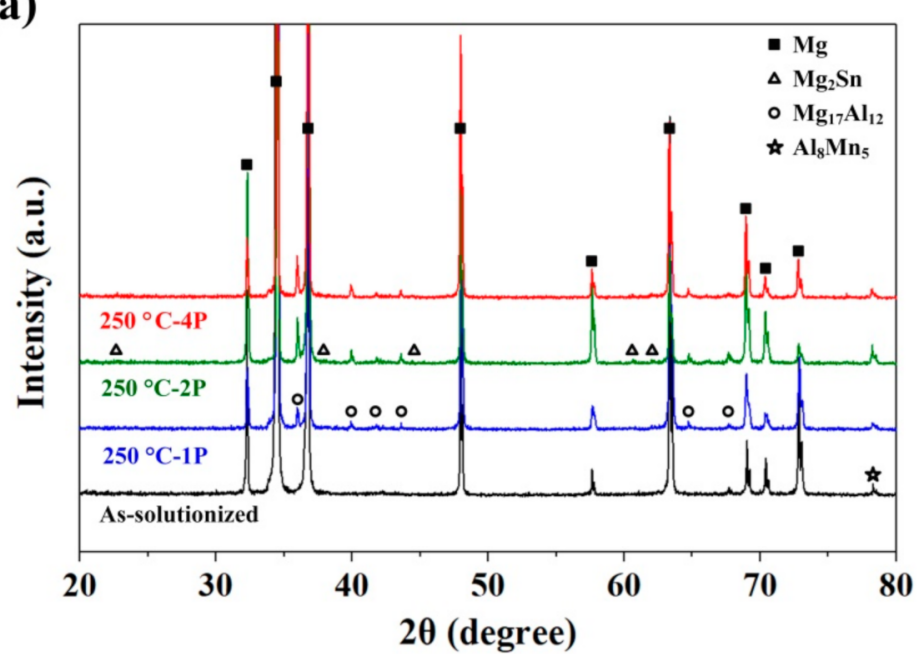

(b)

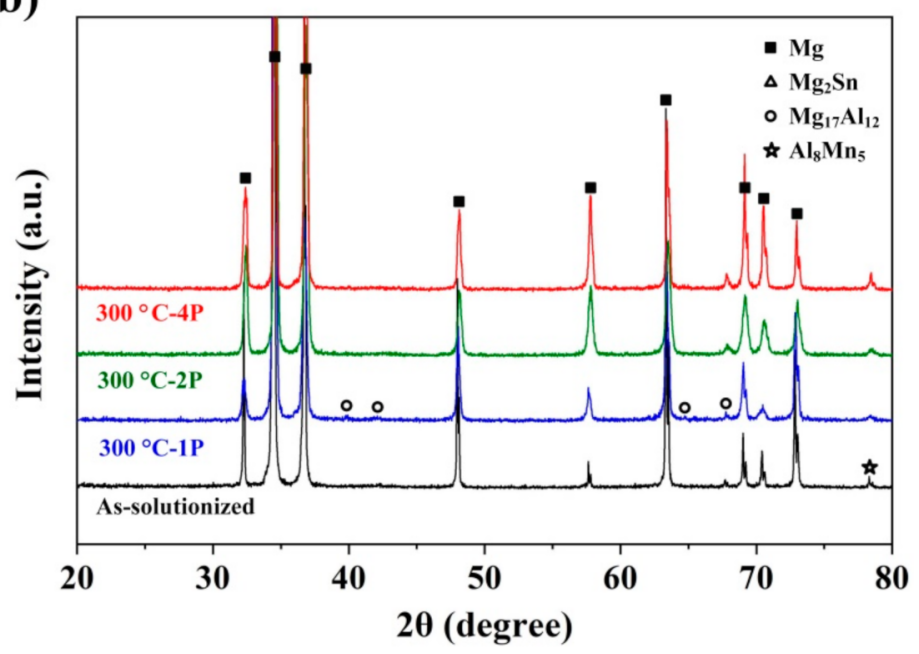

Figure 4. XRD results of the as-solutionized and the $250{ }^{\circ} \mathrm{C}$ and $300{ }^{\circ} \mathrm{C}$ ECAP samples. (a) 1 pass, 2 passes, 4 passes at $250{ }^{\circ} \mathrm{C}$, (b) 1 pass, 2 passes, 4 passes at $300^{\circ} \mathrm{C}$.

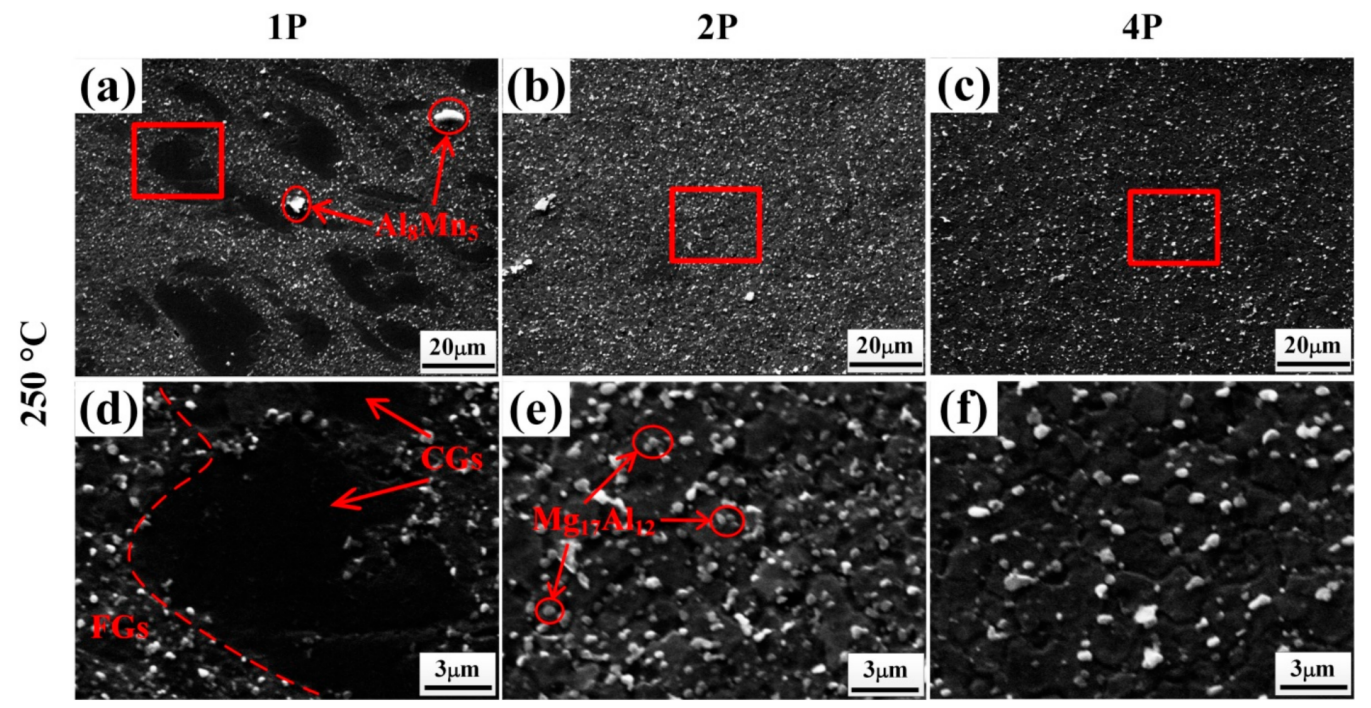

Figure 5. SEM images of ECAP samples deformed at $250{ }^{\circ} \mathrm{C}:(\mathbf{a}, \mathbf{d}) 1$ pass, $(\mathbf{b}, \mathbf{e}) 2$ passes, and $(\mathbf{c}, \mathbf{f})$ 4 passes. $(\mathbf{d}-\mathbf{f})$ are the high-magnification images of $(\mathbf{a}-\mathbf{c})$, respectively. 
Similarly, Figure 6 shows the SEM images of samples deformed at $300{ }^{\circ} \mathrm{C}$. For the $300{ }^{\circ} \mathrm{C}-1 \mathrm{P}$ sample, secondary-phase particles with $\mathrm{f}_{\mathrm{p}}$ of $5 \%$ precipitated. With the ECAP passes increasing, the $\mathrm{f}_{\mathrm{p}}$ of the secondary-phase particles decreased gradually. As shown in Figure $6 \mathrm{c}$, a few $\mathrm{Mg}_{17} \mathrm{Al}_{12}$ phases with a $\mathrm{d}_{\mathrm{p}}$ of $350 \mathrm{~nm}$ precipitated at the grain boundaries in the $300{ }^{\circ} \mathrm{C}-4 \mathrm{P}$ sample. Compared with the $250{ }^{\circ} \mathrm{C}$ samples, less particles precipitated (Figure $6 \mathrm{a}-\mathrm{c}$ ), which led to a larger grain size for the samples deformed at $300{ }^{\circ} \mathrm{C}$.

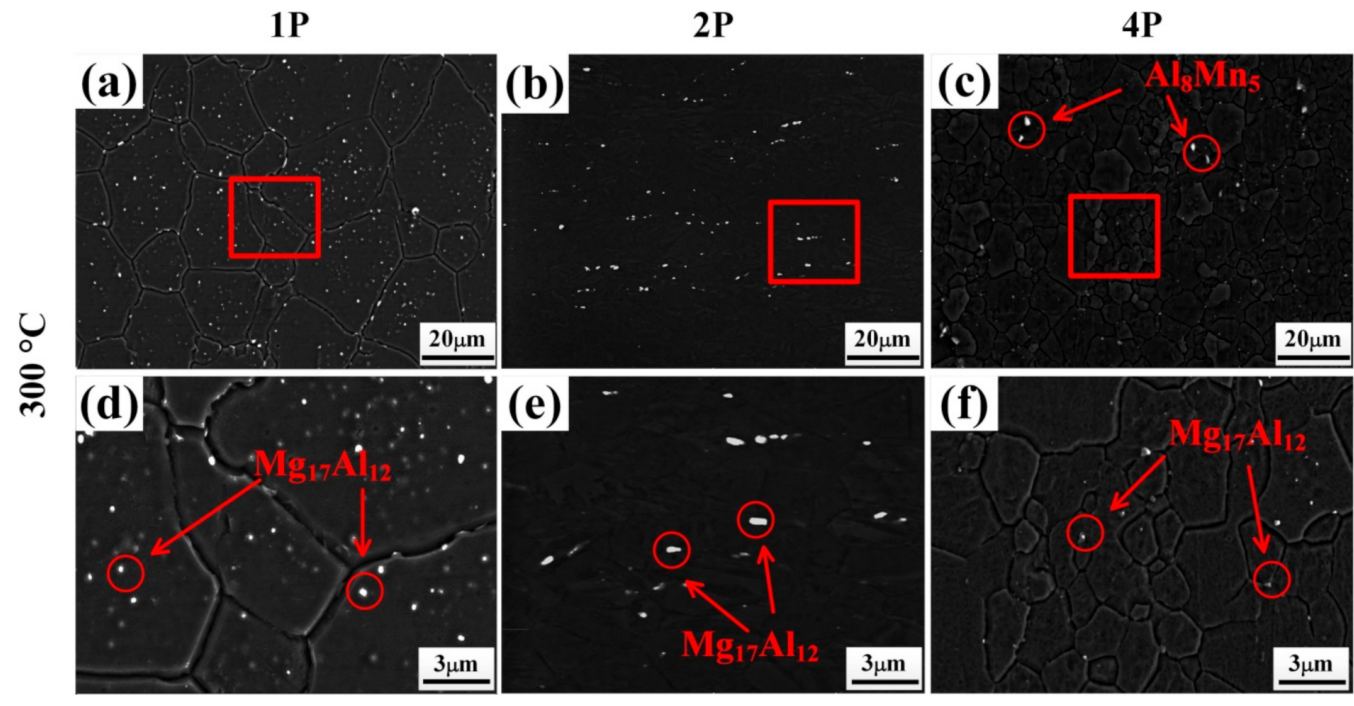

Figure 6. SEM images of ECAP samples at $300^{\circ} \mathrm{C}$ : (a,d) 1 pass, $(\mathbf{b}, \mathbf{e}) 2$ passes, and $(\mathbf{c}, \mathbf{f}) 4$ passes. $(\mathbf{d}-\mathbf{f})$ are the high-magnification images of $(\mathbf{a}-\mathbf{c})$, respectively.

Fractions of recrystallized grains in ECAP-processed samples were evaluated from the EBSD results (Figure 7 ), in which grains with misorientation angles less than $2^{\circ}$, between $2^{\circ}$ and $15^{\circ}$, and above $15^{\circ}$ were defined as deformed grains, substructured grains, and recrystallized grains, respectively. In the $250{ }^{\circ} \mathrm{C}-1 \mathrm{P}$ sample, most grains were substructured grains (Figure 7a). Upon increasing the ECAP passes to two and four, more fully recrystallized grains formed. For samples deformed by ECAP at $300{ }^{\circ} \mathrm{C}$, the fractions of recrystallized grains were much higher compared to the $250{ }^{\circ} \mathrm{C}$ samples. Normally, the values of critical resolved shear stress (CRSS) for the activation of non-basal slip at RT are much larger than those for basal slip. It was found that upon increasing the temperature over $200{ }^{\circ} \mathrm{C}$, the non-basal dislocation was energetically more favorable to move. In addition, adding the Sn element to $\mathrm{Mg}$ alloys can also promote the activity of non-basal slip [7]. Furthermore, compared to basal dislocations, the non-basal dislocations have a higher probability to lock with each other and then form dislocation tangles [37]. Thus, at the early stage of $250{ }^{\circ} \mathrm{C}-\mathrm{CAP}$, more sub-grain boundaries formed. At the same time, due to the pinning of precipitated particles, sub-grain boundaries were hindered from migrating, leading to more sub-grain structures in the $250{ }^{\circ} \mathrm{C}$-ECAP samples.

For samples deformed at $300{ }^{\circ} \mathrm{C}$, although dislocation slip was promoted, annihilation of dislocations was also accelerated, leading to fewer dislocation tangles and fewer nucleation sites for the secondary phase particles. Therefore, sub-grain boundaries can migrate easily due to fewer precipitated particles, resulting in larger grain sizes compared to the $250{ }^{\circ} \mathrm{C}-\mathrm{ECAP}$ samples. 

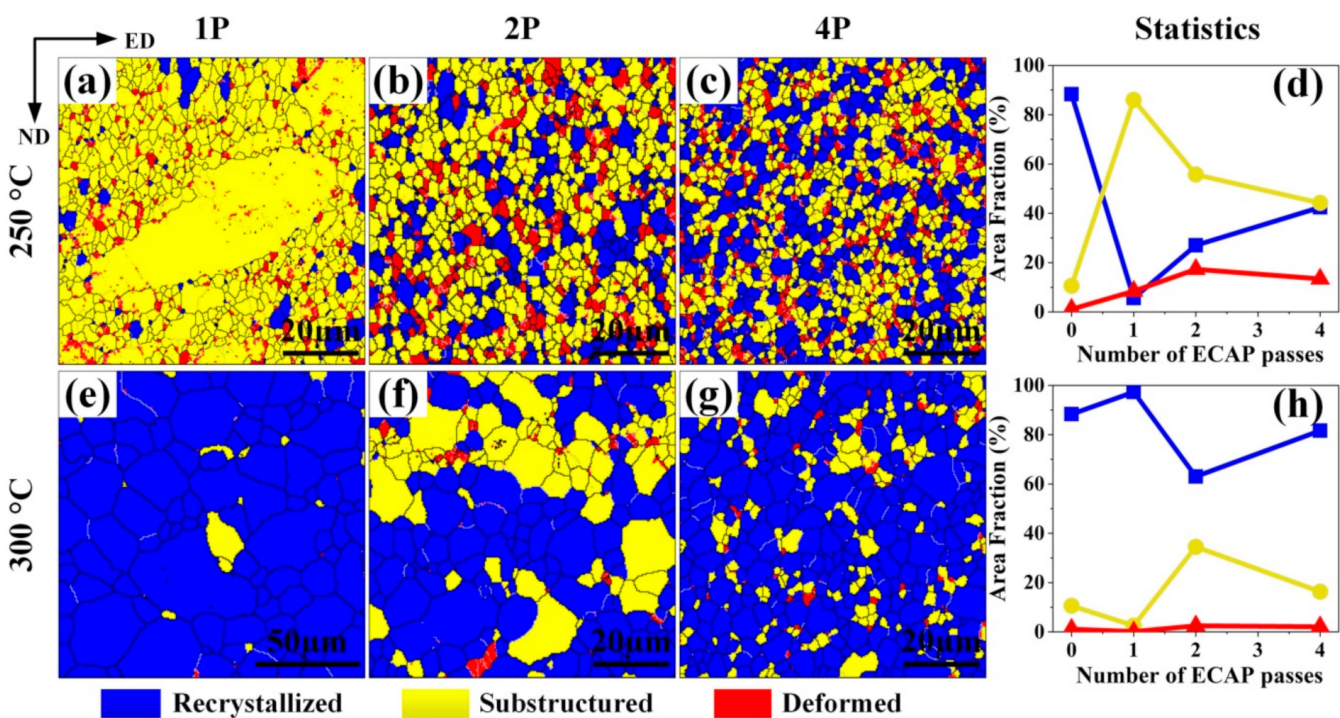

Figure 7. Recrystallization maps of $250{ }^{\circ} \mathrm{C}$ ECAP samples (a-d) and $300{ }^{\circ} \mathrm{C}$ ECAP samples (e-h). (a,e) One pass, $(\mathbf{b}, \mathbf{f})$ two passes, $(\mathbf{c}, \mathbf{g})$ four passes, and $(\mathbf{d}, \mathbf{h})$ the flow curves of recrystallization tendency.

Figure 8 shows the $\{0001\}$ pole figures of the $250{ }^{\circ} \mathrm{C}$ ECAP samples and $300{ }^{\circ} \mathrm{C} \mathrm{ECAP}$ samples. In contrast with the intensive basal texture formed during extrusion, ECAP deformation generated non-basal texture components. After $1 \mathrm{P}-\mathrm{ECAP}$ at $250{ }^{\circ} \mathrm{C}$, the basal planes of most grains moved towards the shear plane (Figure 3a), which was consistent with the results of [38]. Therefore, the c-axes of these grains were approximately parallel to the normal direction of the shear plane, which caused the poles in the $\{0001\}$ pole figure to rotate to a position at $45^{\circ}$ with ND and ED, that is a $45^{\circ}$ texture. The reason for the formation of the $45^{\circ}$ texture may relate to slip planes of prevailing slip systems rotating towards the shear planes (SP) during ECAP [37].
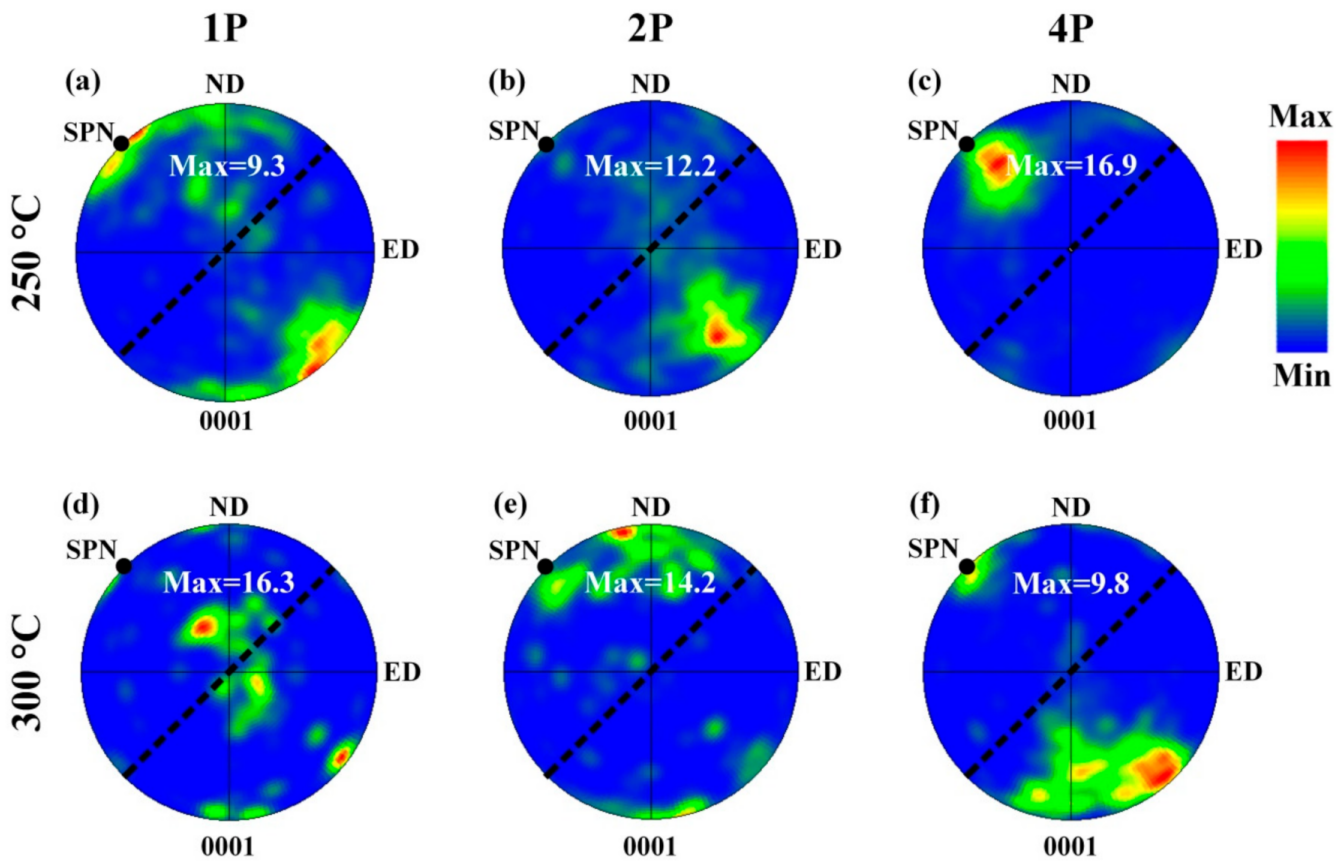

Figure 8. $\{0001\}$ pole figure of the $250{ }^{\circ} \mathrm{C}$-ECAP samples and $(\mathbf{d}-\mathbf{f}) 300{ }^{\circ} \mathrm{C}$-ECAP samples. (a,d) One pass, $(\mathbf{b}, \mathbf{e})$ two passes, and $(\mathbf{c}, \mathbf{f})$ four passes. SP, SPN are abbreviations for shear plane and shear plane normal, respectively. 
Upon increasing the ECAP passes to two, the maximum intensity of the $45^{\circ}$ texture decreased. Coarse grains with the $45^{\circ}$ texture evolved into fine recrystallized grains with random orientations, leading to a decrease of the maximum intensity of the $45^{\circ}$ texture. For the $250^{\circ} \mathrm{C}-4 \mathrm{P}$ sample, the intensity of the $45^{\circ}$ texture increased, mainly because basal slip was more active.

Compared with the $250^{\circ} \mathrm{C}-1 \mathrm{P}$ sample, the distribution of grain orientations of the $300{ }^{\circ} \mathrm{C}-1 \mathrm{P}$ sample was quite different (Figure $8 \mathrm{~d}$ ). It can be seen that the c-axes of some grains rotated towards TD, which was due to the preferred growth of grains with a TD orientation. After two passes at $300{ }^{\circ} \mathrm{C}$, the concentration of the c-axes at ND may be related to the pyramidal slip [39]. Upon further increasing the ECAP passes to four at $300{ }^{\circ} \mathrm{C}$, the maximum intensity was located nearly at $45^{\circ}$ as a result of the basal slip of most grains.

\subsection{Mechanical Properties of ECAP Samples}

Figure 9 shows the tensile test results of the 1P, 2P, and 4P ECAP samples, and the corresponding values are shown in Table 2. For the $250{ }^{\circ} \mathrm{C}$ and $300{ }^{\circ} \mathrm{C}$-ECAP samples, although the $d_{\text {ave }}$ decreased, the corresponding yield strengths decreased. Thus, we needed to consider the change of other strengthening mechanisms that influence the yield strength, i.e., precipitation strengthening $\Delta \sigma_{p}$, solution strengthening $\Delta \sigma_{p}$, and dislocation strengthening $\Delta \sigma_{\mathrm{p}}$.
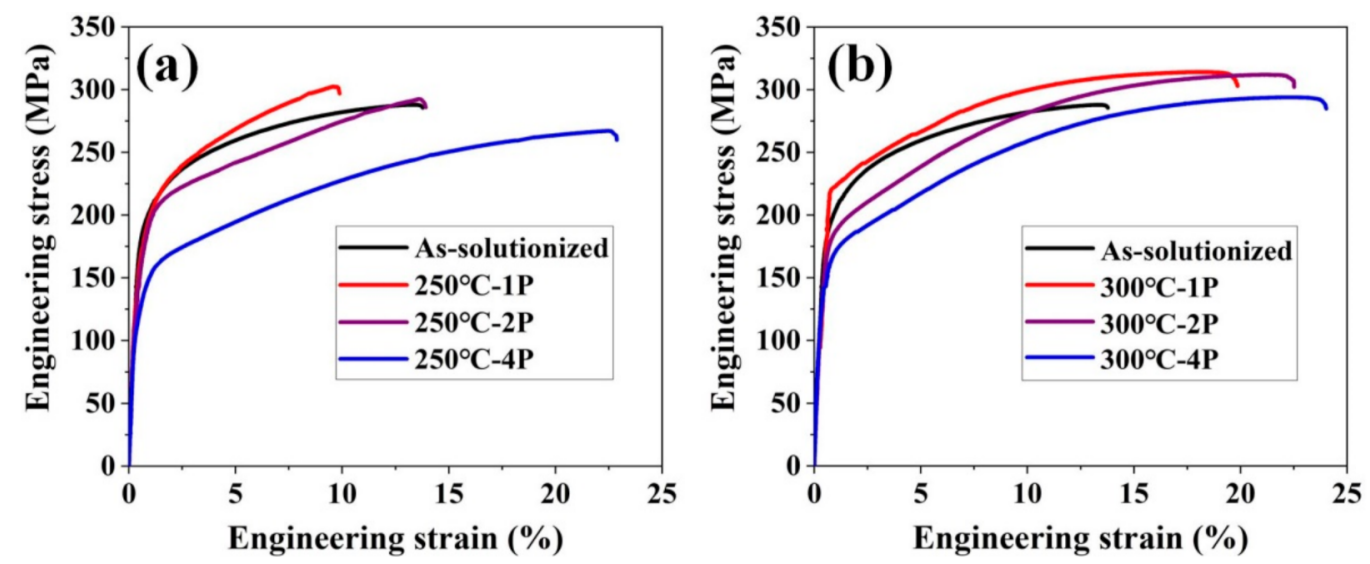

Figure 9. Tensile engineering stress-strain curves of as-solutionized samples and ECAPed samples. (a) 1 pass, 2 passes, 4 passes at $250{ }^{\circ} \mathrm{C}$, (b) 1 pass, 2 passes, 4 passes at $300{ }^{\circ} \mathrm{C}$.

Table 2. Room temperature tensile properties of samples deformed at $250{ }^{\circ} \mathrm{C}$ and $300{ }^{\circ} \mathrm{C}$.

\begin{tabular}{cccc}
\hline Sample & $\left.\boldsymbol{\sigma}_{\mathbf{0 . 2}} \mathbf{( M P a}\right)$ & $\left.\boldsymbol{\sigma}_{\mathbf{b}} \mathbf{( M P a}\right)$ & $\boldsymbol{\delta}_{\mathbf{p}}(\mathbf{\%})$ \\
\hline As-solutionized & 185 & 288 & 13.4 \\
$250{ }^{\circ} \mathrm{C}-1 \mathrm{P}$ & 165 & 302 & 9.5 \\
$250{ }^{\circ} \mathrm{C}-2 \mathrm{P}$ & 160 & 293 & 13.4 \\
$250{ }^{\circ} \mathrm{C}-4 \mathrm{P}$ & 124 & 267 & 22.6 \\
$300^{\circ} \mathrm{C}-1 \mathrm{P}$ & 211 & 314 & 19.4 \\
$300{ }^{\circ} \mathrm{C}-2 \mathrm{P}$ & 166 & 312 & 22.1 \\
$300^{\circ} \mathrm{C}-4 \mathrm{P}$ & 142 & 294 & 23.6 \\
\hline
\end{tabular}

Precipitation strengthening $\left(\Delta \sigma_{\mathrm{p}}\right)$ can be calculated through the Orowan equation [40]:

$$
\Delta \sigma_{\mathrm{p}}=\mathrm{M} \frac{\mathrm{Gb}}{2 \pi \sqrt{1-\mathrm{v}}\left(\frac{0.953}{\sqrt{\mathrm{f}}}-1\right) \mathrm{d}_{\mathrm{p}}} \ln \frac{\mathrm{d}_{\mathrm{p}}}{\mathrm{b}}
$$

where $\mathrm{M}$ is the Taylor factor (2.5 [41] ), $\mathrm{G}$ is the shear modulus $\left(1.66 \times 10^{4} \mathrm{MPa}\right.$ for $\mathrm{Mg}$ [41]), $\mathrm{b}$ is the Burgers vector $\left(3.2 \times 10^{-10} \mathrm{~m}\right.$ for $\mathrm{Mg}$ [41]), $\mathrm{v}$ is Poisson's ratio (0.35 for Mg [41]), 
and $d_{p}$ and $f_{p}$ are the average phase particles' size and the volume fraction of particles, respectively.

Solution strengthening for the ATZ611 alloy was mainly caused by Al, Zn, and Sn solute atoms. Solution strengthening $\left(\Delta \sigma_{s}\right)$ was calculated by Equation (2) according to the Deruyttere and Gypen theoretical model [42]:

$$
\Delta \sigma_{\mathrm{s}}=\left(k_{\mathrm{Al}}^{\frac{1}{n}} C_{\mathrm{Al}}+k_{\mathrm{Zn}}^{\frac{1}{n}} C_{\mathrm{Zn}}+k_{\mathrm{Sn}}^{\frac{1}{n}} C_{\mathrm{Sn}}\right)^{n}
$$

where $\mathrm{k}_{\mathrm{Al}}$ is $196 \mathrm{MPa}$ (at.) $)^{-2 / 3}$ [43], $\mathrm{k}_{\mathrm{Zn}}$ is $905 \mathrm{MPa}$ (at.) $)^{-2 / 3}$ [43], $\mathrm{k}_{\mathrm{Sn}}$ is $52 \mathrm{MPa}$ (at.) ${ }^{-2 / 3}$ [42], and $\mathrm{n}$ is constant as $2 / 3$ [44]. In this work, we assumed that $\sim 6 \mathrm{wt} . \% \mathrm{Al}, \sim 1 \mathrm{wt} . \% \mathrm{Zn}$, and $\sim 0.9 \mathrm{wt} . \% \mathrm{Sn}$ atoms were in a solid solution for the as-solutionized samples. Because of the precipitation of the secondary phase during ECAP deformation at $250{ }^{\circ} \mathrm{C}$ and $300^{\circ} \mathrm{C}$, approximately $3 \mathrm{wt} . \% \mathrm{Al}$ and $\sim 1 \mathrm{wt} . \% \mathrm{Zn}$ atoms were assumed to be in the solid solution for the $250{ }^{\circ} \mathrm{C}$ sample, while $\sim 6 \mathrm{wt} . \% \mathrm{Al}, \sim 1 \mathrm{wt} . \% \mathrm{Zn}$, and $\sim 0.9 \mathrm{wt} . \%$ Sn were assumed to be in the solid solution for the $300{ }^{\circ} \mathrm{C}$ sample. The values of solution strengthening were estimated to be $\sim 31 \mathrm{MPa}$ for $250{ }^{\circ} \mathrm{C}$ samples and $\sim 40 \mathrm{MPa}$ for $300^{\circ} \mathrm{C}$ samples

The dislocation strengthening was calculated according to the Taylor formula:

$$
\Delta \sigma_{\mathrm{d}}=\alpha \mathrm{M}^{\mathrm{T}} \mathrm{Gb} \rho^{\frac{1}{2}}
$$

where $\rho$ is the dislocation density. The parameter $\alpha$ was 0.6 for basal-basal dislocation interaction. The dislocation density $\rho$ of each sample was the geometric necessary dislocation density, which was obtained from the EBSD results, as shown in Table 1.

The strength increase caused by secondary-phase particles, dislocations, and solution atoms were subtracted from the measured yield strength (Table 3), and $\sigma_{0.2}-\left(\Delta \sigma_{p}+\Delta \sigma_{s}+\Delta \sigma_{d}\right)$ should be mainly attributed to grain boundary strengthening. From 3.1, it was found that $\mathrm{d}_{\mathrm{ave}}$ decreased with the increase of ECAP passes, which should lead to an increase of grain boundary strengthening, i.e., $\sigma_{0.2}-\left(\Delta \sigma_{p}+\Delta \sigma_{s}+\Delta \sigma_{d}\right)$. However, as shown in Table 3, the calculated $\sigma_{0.2}-\left(\Delta \sigma_{\mathrm{p}}+\Delta \sigma_{\mathrm{s}}+\Delta \sigma_{\mathrm{d}}\right)$ values showed a different trend, which could be related to the change of the H-P coefficient $\mathrm{k}$ caused by textures [45]. Texture affects $\mathrm{k}$ mainly by changing the proportion of different slip modes [45]. If the basal planes of most grains were parallel to the theoretical shear plane and the tensile force was along ED at the same time, it would be easier to activate basal slip, which would result in a smaller $\mathrm{k}$ value. Thus, the decrease in $\sigma_{0.2}-\left(\Delta \sigma_{\mathrm{p}}+\Delta \sigma_{\mathrm{s}}+\Delta \sigma_{\mathrm{d}}\right)$ was a result of the reduction of $\mathrm{k}$. Moreover, for the $300^{\circ} \mathrm{C}-1 \mathrm{P}$ sample, in addition to the $45^{\circ}$ texture, concentrated poles around TD could be observed. Basal slips were less easy for these "TD"-orientation grains during tension along the ED, resulting in a higher $\mathrm{k}$ value and thus the larger value of $\sigma_{0.2}$ $-\left(\Delta \sigma_{\mathrm{p}}+\Delta \sigma_{\mathrm{s}}+\Delta \sigma_{\mathrm{d}}\right)$.

\begin{tabular}{|c|c|c|c|c|c|}
\hline Sample & $\Delta \sigma_{\mathrm{p}}(\mathrm{MPa})$ & $\Delta \sigma_{\mathrm{s}}(\mathrm{MPa})$ & $\Delta \sigma_{\mathrm{d}}(\mathrm{MPa})$ & $\left(\Delta \sigma_{\mathrm{p}}+\Delta \sigma_{\mathrm{s}}+\Delta \sigma_{\mathrm{d}}\right)(\mathrm{MPa})$ & $\sigma_{0.2}-\left(\Delta \sigma_{\mathrm{p}}+\Delta \sigma_{\mathrm{s}}+\Delta \sigma_{\mathrm{d}}\right)(\mathrm{MPa})$ \\
\hline As-solutionized & - & 40 & - & 40 & 145 \\
\hline $250{ }^{\circ} \mathrm{C}-1 \mathrm{P}$ & 36.5 & 31 & 20 & 87.5 & 77.5 \\
\hline $250{ }^{\circ} \mathrm{C}-2 \mathrm{P}$ & 34.9 & 31 & 14 & 79.9 & 80.1 \\
\hline $250{ }^{\circ} \mathrm{C}-4 \mathrm{P}$ & 19.8 & 31 & 13.5 & 65.3 & 60.7 \\
\hline $300{ }^{\circ} \mathrm{C}-1 \mathrm{P}$ & 14.1 & 40 & 7.8 & 61.9 & 149.1 \\
\hline $300{ }^{\circ} \mathrm{C}-2 \mathrm{P}$ & 9.9 & 40 & 12.4 & 62.3 & 103.7 \\
\hline $300{ }^{\circ} \mathrm{C}-4 \mathrm{P}$ & 9.3 & 40 & 10 & 58.3 & 82.7 \\
\hline
\end{tabular}

Table 3. Contribution of different strengthening mechanisms to the yield strength of samples deformed at $250{ }^{\circ} \mathrm{C}$ and $300{ }^{\circ} \mathrm{C}$.

\section{Conclusions}

The influence of ECAP deformation temperatures $\left(250{ }^{\circ} \mathrm{C}\right.$ and $\left.300{ }^{\circ} \mathrm{C}\right)$ on the microstructure, texture, and mechanical properties of a Mg-6Al-1Zn-0.9Sn alloy was studied. The main conclusions are as follows: 
1. The smallest $\mathrm{d}_{\mathrm{ave}}$ of $\sim 1.9 \mu \mathrm{m}$ was obtained after $4 \mathrm{P}$ ECAP at $250{ }^{\circ} \mathrm{C}$. Different rates of grain refinement at $250{ }^{\circ} \mathrm{C}$ and $300{ }^{\circ} \mathrm{C}$ were caused by the different amounts of precipitated secondary-phase particles.

2. The strong basal texture in as-solutionized alloy transformed to a non-basal texture during ECAP, with $\{0001\}$ planes inclined $\sim 45^{\circ}$ to ED. Compared to the $250{ }^{\circ} \mathrm{C}$ sample, c-axes of grains in the $300{ }^{\circ} \mathrm{C}$ sample rotated to $45^{\circ}$ at a slower rate.

3. The yield strength of the as-ECAPed alloys was significantly lower than that of the as-solutionized alloy. The formation of $45^{\circ}$ textures facilitated the activation of basal slips, which resulted in a low value of H-P coefficient $\mathrm{k}$. The yield strength of the as-ECAPed alloys decreased greatly as the $\mathrm{K}$ value became smaller.

Author Contributions: Each author equally contributed to the paper. Conceptualization, H.X., Z.-P.G., P.-Y.Z. and P.-K.M.; data curation, Z.-P.G., Y.Z. and P.-Y.Z.; formal analysis, H.X., Z.-P.G. and P.-Y.Z.; funding acquisition, H.X.; investigation, Z.-P.G., Y.Z. and P.-Y.Z.; methodology, H.X., Z.-P.G., P.-Y.Z. and P.-K.M.; project administration, H.X.; resources, Y.Z. and P.-Y.Z.; supervision, H.X. and P.-K.M.; validation, Z.-P.G. and P.-Y.Z.; visualization, Z.-P.G. and P.-Y.Z.; writing-original draft preparation, Z.-P.G. and P.-Y.Z.; writing—review and editing, H.X., Z.-P.G., P.-Y.Z. and P.-K.M. All authors read and agreed to the published version of the manuscript.

Funding: Acknowledgement is given to the financial support from the Science and Technology Development Program of Jilin Province (No. 20190302060GX).

Institutional Review Board Statement: Not applicable.

Informed Consent Statement: Not applicable.

Data Availability Statement: Data sharing not applicable. No new data were created or analyzed in this study. Data sharing is not applicable to this article.

Conflicts of Interest: The authors declare no conflict of interest.

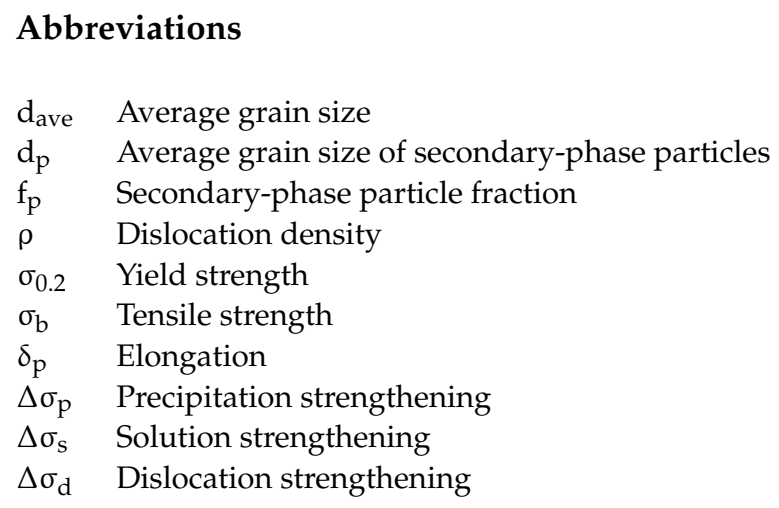

\section{References}

1. Gautam, P.C.; Biswas, S. On the possibility to reduce ECAP deformation temperature in magnesium: Deformation behaviour, dynamic recrystallization and mechanical properties. Mater. Sci. Eng. A 2021, 812, 141103. [CrossRef]

2. Pollock, T.M. Weight loss with magnesium alloys. Science 2010, 328, 986-987. [CrossRef] [PubMed]

3. Minárik, P.; Zemková, M.; Veselý, J.; Bohlen, J.; Knapek, M.; Král, R. The effect of Zr on dynamic recrystallization during ECAP processing of Mg-Y-RE alloys. Mater. Charact. 2021, 174, 111033. [CrossRef]

4. Zhang, S.H.; Zhang, K.; Xu, Y.C.; Wang, Z.T.; Xu, Y.; Wang, Z.G. Deep-drawing of magnesium alloy sheets at warm temperatures. J. Mater. Process. Technol. 2007, 185, 147-151. [CrossRef]

5. Khomamizadeh, F.; Nami, B.; Khoshkhooei, S. Effect of rare-earth element additions on high-temperature mechanical properties of AZ91 magnesium alloy. Metall. Mater. Trans. A 2005, 36, 3489-3494. [CrossRef]

6. Lü, Y.Z.; Wang, Q.D.; Zeng, X.Q.; Ding, W.J.; Zhai, C.Q.; Zhu, Y.P. Effects of rare earths on the microstructure, properties and fracture behavior of Mg-Al alloys. Metall. Mater. Trans. A 2000, 278, 66-76. [CrossRef]

7. Wang, H.Y.; Zhang, N.; Wang, C.; Jiang, Q.C. First-principles study of the generalized stacking fault energy in Mg-3Al-3Sn alloy. Scr. Mater. 2011, 65, 723-726. [CrossRef]

8. Kang, D.H.; Park, S.S.; Kim, N.J. Development of creep resistant die cast Mg-Sn-Al-Si alloy. Metall. Mater. Trans. A 2005, 413, 555-560. [CrossRef] 
9. Wang, Y.M.; Chen, M.W.; Zhou, F.H.; Ma, E. High tensile ductility in a nanostructured metal. Nature 2002, 419, 912-915. [CrossRef]

10. Zhang, T.T.; Cui, H.W.; Cui, X.L.; Zhao, E.T.; Pan, Y.K.; Feng, R.; Jia, Q.R.; Zhao, J. Ductility enhancement in an as-extruded Mg-5.5Zn-0.8Zr alloy by Sm alloying. J. Alloy. Compd. 2019, 784, 1130-1138. [CrossRef]

11. Sanyal, S.; Kanodia, S.; Saha, R.; Bandyopadhyay, T.K.; Mandal, S. Influence of hard plate hot forging temperature on the microstructure, texture and mechanical properties in a lean Mg-Zn-Al alloy. J. Alloy. Compd. 2019, 800, 343-354. [CrossRef]

12. Hono, K.; Mendis, C.L.; Sasaki, T.T.; Ohishi, K. Towards the development of heat-treatable high-strength wrought Mg alloys. Scr. Mater. 2010, 63, 710-715. [CrossRef]

13. Zhu, S.Q.; Yan, H.G.; Liao, X.Z.; Moody, S.J.; Sha, G.; Wu, Y.Z.; Ringer, S.P. Mechanisms for enhanced plasticity in magnesium alloys. Acta Mater. 2015, 82, 344-355. [CrossRef]

14. Wang, X.J.; Xu, D.K.; Wu, R.Z.; Chen, X.B.; Peng, Q.M.; Jin, L.; Xin, Y.C.; Zhang, Z.Q.; Liu, Y.; Chen, X.H.; et al. What is going on in magnesium alloys? J. Mater. Sci. Technol. 2018, 34, 245-247. [CrossRef]

15. Fu, Y.T.; Sun, J.P.; Yang, Z.Q.; Xu, B.Q.; Han, J.; Chen, Y.F.; Jiang, J.H.; Ma, A.B. Aging behavior of a fine-grained Mg-10.6Gd-2Ag alloy processed by ECAP. Mater. Charact. 2020, 165, 110398. [CrossRef]

16. Manjunath, G.K.; Udaya Bhat, K.; Preetham Kumar, G.V.; Ramesh, M.R. Microstructure and Wear Performance of ECAP Processed Cast Al-Zn-Mg Alloys. Trans. Indian Inst. Met. 2018, 71, 1919-1931. [CrossRef]

17. Figueiredo, R.B.; Langdon, T.G. Principles of grain refinement in magnesium alloys processed by equal-channel angular pressing. J. Mater. Sci. 2009, 44, 4758-4762. [CrossRef]

18. Azushima, A.; Kopp, R.; Korhonen, A.; Yang, D.; Micari, F.; Lahoti, G.; Groche, P.; Yanagimoto, J.; Tsuji, N.; Rosochowski, A.; et al. Severe plastic deformation (SPD) processes for metals. CIRP Ann. 2008, 57, 716-735. [CrossRef]

19. Gopi, K.R.; Nayaka, H.S.; Sahu, S. Corrosion Behavior of ECAP-Processed AM90 Magnesium Alloy. Arab. J. Sci. Eng. 2018, 43, 4871-4878. [CrossRef]

20. Lei, W.; Zhang, H. Analysis of microstructural evolution and compressive properties for pure Mg after room-temperature ECAP. Mater. Lett. 2020, 271, 127781. [CrossRef]

21. Shan, Z.; Yang, J.; Fan, J.; Zhang, H.; Zhang, Q.; Wu, Y.; Li, W.; Dong, H.; Xu, B. Extraordinary mechanical properties of AZ61 alloy processed by ECAP with $160^{\circ}$ channel angle and EPT. J. Magnes. Alloys 2021, 9, 548-559. [CrossRef]

22. Sun, J.; Xu, B.; Yang, Z.; Zhuo, X.; Han, J.; Wu, Y.; Song, D.; Liu, H.; Jiang, J.; Ma, A. Developing an industrial-scale ECAP Mg-Al-Zn alloy with multi-heterostructure for synchronously high strength and good ductility. Mater. Charact. 2020, 164, 110341. [CrossRef]

23. Huang, H.; Liu, H.; Wang, C.; Sun, J.; Bai, J.; Xue, F.; Jiang, J.; Ma, A. Potential of multi-pass ECAP on improving the mechanical properties of a high-calcium-content Mg-Al-Ca-Mn alloy. J. Magnes. Alloys 2019, 7, 617-627. [CrossRef]

24. Xu, B.; Sun, J.; Yang, Z.; Xiao, L.; Zhou, H.; Han, J.; Liu, H.; Wu, Y.; Yuan, Y.; Zhuo, X.; et al. Microstructure and anisotropic mechanical behavior of the high-strength and ductility AZ91 Mg alloy processed by hot extrusion and multi-pass RD-ECAP. Mater. Sci. Eng. A 2020, 780, 139191. [CrossRef]

25. Xu, Q.; Ma, A.; Li, Y.; Saleh, B.; Yuan, Y.; Jiang, J.; Ni, C. Enhancement of Mechanical Properties and Rolling Formability in AZ91 Alloy by RD-ECAP Processing. Materials 2019, 12, 3503. [CrossRef]

26. Gopi, K.R.; Shivananda Nayaka, H.; Sahu, S. Microstructural Evolution and Strengthening of AM90 Magnesium Alloy Pro-cessed by ECAP. Arab. J. Sci. Eng. 2017, 42, 4635-4647. [CrossRef]

27. Sarebanzadeh, M.; Roumina, R.; Mahmudi, R.; Wu, G.H.; Jafari Nodooshan, H.R. Enhancement of superplasticity in a fi-ne-grained Mg-3Gd-1Zn alloy processed by equal-channel angular pressing. Mater. Sci. Eng. A 2015, 646, 249-253. [CrossRef]

28. Mostaed, E.; Fabrizi, A.; Dellasega, D.; Bonollo, F.; Vedani, M. Grain size and texture dependence on mechanical properties, asymmetric behavior and low temperature superplasticity of ZK60 Mg alloy. Mater. Charact. 2015, 107, 70-78. [CrossRef]

29. Mostaed, E.; Fabrizi, A.; Dellasega, D.; Bonollo, F.; Vedani, M. Microstructure, mechanical behavior and low temperature superplasticity of ECAP processed ZM21 Mg alloy. J. Alloys Compd. 2015, 638, 267-276. [CrossRef]

30. Liao, Q.Y.; Hu, W.X.; Le, Q.C.; Chen, X.R.; Hu, K.; Cheng, C.L.; Hu, C.L. Microstructure, Mechanical Properties and Texture Evolution of Mg-Al-Zn-La-Gd-Y Magnesium Alloy by Hot Extrusion and Multi-Pass Rolling. Acta Metall. Sin. 2020, 33, 1359-1368. [CrossRef]

31. Park, S.H.; Kim, S.-H.; Yu, H.; Kim, H.S.; You, B.S. Anisotropic compressive behavior of extruded Mg alloy plates with different width-thickness ratios. Mater. Sci. Eng. A 2016, 675, 11-18. [CrossRef]

32. Dogan, E.; Wang, S.; Vaughan, M.W.; Karaman, I. Dynamic precipitation in Mg-3Al-1Zn alloy during different plastic de-formation modes. Acta Mater. 2016, 116, 1-13. [CrossRef]

33. Guo, F.; Zhang, D.; Yang, X.; Jiang, L.; Pan, F. Strain-induced dynamic precipitation of Mg17Al12 phases in Mg-8Al alloys sheets rolled at 748 K. Mater. Sci. Eng. A 2015, 636, 516-521. [CrossRef]

34. Jo, S.M.; Kim, S.D.; Kim, T.-H.; Go, Y.; Yang, C.-W.; You, B.S.; Kim, Y.M. Sequential precipitation behavior of Mg17Al12 and Mg2Sn in Mg-8Al-2Sn-1Zn alloys. J. Alloys Compd. 2018, 749, 794-802. [CrossRef]

35. Robson, J.; Henry, D.; Davis, B. Particle effects on recrystallization in magnesium-manganese alloys: Particle-stimulated nucleation. Acta Mater. 2009, 57, 2739-2747. [CrossRef]

36. Cheng, W.; Tian, L.; Wang, H.; Bian, L.; Yu, H. Improved tensile properties of an equal channel angular pressed (ECAPed) Mg-8Sn-6Zn-2Al alloy by prior aging treatment. Mater. Sci. Eng. A 2017, 687, 148-154. [CrossRef]

37. Krajňák, T.; Minárik, P.; Gubicza, J.; Máthis, K.; Kužel, R.; Janeček, M. Influence of equal channel angular pressing routes on texture, microstructure and mechanical properties of extruded AX41 magnesium alloy. Mater. Charact. 2017, 123, 282-293. [CrossRef] 
38. Mukai, T.; Yamanoi, M.; Watanabe, H.; Higashi, K. Ductility enhancement in AZ31 magnesium alloy by controlling its grain structure. Scr. Mater. 2001, 45, 89-94. [CrossRef]

39. Minárik, P.; Král, R.; Č́ž̌ek, J.; Chmelík, F. Effect of different c/a ratio on the microstructure and mechanical properties in magnesium alloys processed by ECAP. Acta Mater. 2016, 107, 83-95. [CrossRef]

40. Nie, J. Effects of precipitate shape and orientation on dispersion strengthening in magnesium alloys. Scr. Mater. 2003, 48, 1009-1015. [CrossRef]

41. Kim, W.J.; Jeong, H.G.; Jeong, H.T. Achieving high strength and high ductility in magnesium alloys using severe plastic de-formation combined with low-temperature aging. Scr. Mater. 2009, 61, 1040-1043. [CrossRef]

42. Shi, B.; Chen, R.; Ke, W. Solid solution strengthening in polycrystals of Mg-Sn binary alloys. J. Alloys Compd. 2011, 509, 3357-3362. [CrossRef]

43. Gao, L.; Chen, R.; Han, E. Effects of rare-earth elements Gd and Y on the solid solution strengthening of Mg alloys. J. Alloys Compd. 2009, 481, 379-384. [CrossRef]

44. Cheng, W.L.; Tian, Q.W.; Yu, H.; Zhang, H.; You, B.S. Strengthening mechanisms of indirect-extruded Mg-Sn based alloys at room temperature. J. Magnes. Alloys 2014, 2, 299-304. [CrossRef]

45. Yu, H.; Xin, Y.; Wang, M.; Liu, Q. Hall-Petch relationship in Mg alloys: A review. J. Mater. Sci. Technol. 2018, 34, 248-256. [CrossRef] 